\title{
Effect of in-situ Incorporation Green Manures on Soil Organic Carbon, pH, Bulk Density and Economics Involved in Its Incorporation
}

\author{
Ghous Ali*, Ch. Pulla Rao, A.S. Rao and Y. Ashoka Rani \\ Agronomy, ICAR-CSWRI, ARC, Bikaner, India \\ *Corresponding author
}

\section{A B S T R A C T}

\section{Keywords}

Green Manures,

Soil, Organic

Carbon, pH, Bulk

Density

Article Info

Accepted:

04 August 2018

Available Online:

10 September 2018
A field experiment was conducted at the Agricultural College Farm, Bapatla, to study the effect of in-situ incorporation of dhaincha, sunnhemp and pillipesara green manure at 60 , 45 and 30 DAS. Highest biomass production was recorded from 60 day aged dhaincha. Soil organic carbon content 45 days after of incorporation of green manures (30 DAS of maize) was recorded maximum $(0.73 \%)$ from dhaincha incorporated plot which was significantly superior to sunnhemp and pillipesara. Age of incorporation of green manure also had a significant effect and maximum organic carbon content $(0.75 \%)$ was recorded at 60 days age of incorporation of green manures. A similar trend in organic carbon content was observed after harvest of maize which was decreased. The $\mathrm{pH}$ of the soil 30 DAS as well as at harvest and bulk density at harvest of maize did not vary significantly either due to incorporation of different green manures or their ages of incorporation. Among all the treatments tried, highest return per rupee investment (Rs 4.01) was obtained where dhaincha was incorporated at 45 days.

\section{Introduction}

Earlier, lot of organic manures and FYM were added to soil. Farmers were able to grow crops even without fertilizer. With the advent of inorganic synthetic fertilizers and intensive cultivation practice the usage of farm yard manure and other organic sources is reduced. At present, the level of organic carbon has gone down to $0.2-1.0 \%$. Soil fertility is closely linked to soil organic matter. The decrease in productivity is closely tied to a decline in the levels of soil organic matter. In poor soils, it is organic matter that determines the improvement of physical aspects, water retention, and biological activity, as well as the storage and slow release of nutrients. Decreasing levels of organic carbon has aggravated the problems like poor Soil Structure, Soil Compaction, decreased porosity, unstable soil aggregate, low water holding capacity, decreased microbial population and reduced nutrient availability, Soil Erosion etc. So an attempt has been to increase the organic carbon content in soil by incorporating green manures by conducting this experiment.

\section{Materials and Methods}

The field experiment was conducted during the kharif season of 2012-2013 at the 
Agricultural College Farm, Bapatla. The soil was clay loam in texture, alkaline in reaction with $\mathrm{p}^{\mathrm{H}} 8.1$, low-in organic carbon $(0.40 \%)$ and available nitrogen $\left(212 \mathrm{~kg} \mathrm{ha}^{-1}\right)$, medium in available phosphorus (31 $\mathrm{kg} \mathrm{ha}^{-1}$ ) and potassium (301 kg ha-1). Three different green manures (dhaincha, sunnhemp and pillipesara) and their three different ages of incorporation (60 days, 45 days and 30 days) were tested in factorial RBD with single control (no green manure) and replicated thrice. The organic carbon content, $\mathrm{pH}$ was recorded at 30 DAS of maize and after harvest of maize. Bulk density was recorded after harvest of maize crop. The additional net returns accrued due to incorporation of green manure crops were calculated. Returns per rupee invested were worked out on the basis of net returns in terms of rupees after deducting the cost of treatments from gross returns.

\section{Results and Discussion}

The data revealed that among different green manure crops, dhaincha (13.8 t/ha) recorded maximum biomass production which is significantly superior to sunnhemp (12.6 t/ha) and pillipesara $(9.1 \mathrm{t} / \mathrm{ha})$. A similar significant difference was observed between sunnhemp and pillipesara. Similarly, age of green manures also had a significant effect on biomass production.

The 60 day aged green manure recorded maximum (18.1 t/ha) biomass which was found significantly superior to 45 day (10.4 t/ha) and 30 day (7.0 t/ha) aged green manures. Highest biomass was produced in 60 day dhaincha $(20.6 \mathrm{t} / \mathrm{ha})$ followed by 60 day sunnhemp (18.8 t/ha) which in turn is followed by dhaincha 45 day (12.7 t/ha). Least biomass was produced in 30 day pillipesara (5.3 t/ha).

Climatic condition might have favoured the better performance of dhaincha as it can grow in wet as well as dry conditions. Growth rate of the plant is slow in the initial stage as plants are in lag phase. Maximum growth and biomass production occurs in grand growth phase.

Growth of the plant continues from grand growth phase to senescence phase but the growth is slow. Since dhaincha comes to flowering at 45 to 47 days there is rapid biomass accumulation upto that stage, biomass accumulation continues even after flowering but, the biomass accumulation slows down. Whereas, sunnhemp comes to flowering by 72 to 74 days that may be the reason for lesser biomass accumulation by sunnhemp at 60 day than dhaincha at 60 days age. Pillipesara recorded least biomass among all green manures at 60 days age might be because of the genetic potential of the plant as well as the prevailing climatic conditions. Earlier Bharadwaj et al., (1981), Ghai et al., (1985) and Salam et al., (1989) also reported similar results which are in tune with the present findings.

Organic carbon content (\%) of the soil 30 DAS of maize and at harvest reveals that organic carbon content of the soil varied significantly due to incorporation of different green manures as well as due to age of incorporation of green manures but not their interaction.

Maximum organic carbon content $(0.73 \%)$ in soil was recorded where dhaincha was incorporated followed by sunnhemp $(0.71 \%)$ and pillipesara (0.64\%). Organic carbon contents in dhaincha and pillipesara incorporated plots were found to be significantly different with each other. However, organic carbon content when compared between dhaincha and sunnhemp as well as sunnhemp and pillipesara incorporated plot was remained on a par with each other. Due to age of incorporation of green manures, 
maximum organic carbon content in soil was recorded where green manures were incorporated at 60 days $(0.75 \%)$ followed by 45 days $(0.68 \%)$ and 30 days $(0.65 \%)$. Organic carbon content in 60 days incorporated green manures was found to be significantly superior to 45 days and 30 days incorporated green manures. However, organic carbon content in 45 days and 30 days incorporated green manure did not differ significantly with each other. The entire green manure treated plots recorded a higher organic carbon content which were found to be significantly superior to control where no green manure was incorporated. A similar trend was observed in organic carbon content after harvest of maize though there was a decrease in organic carbon content in the soil.

Increase in organic carbon content in the soil depends on the quantity of organic matter added to the soil. As it is already discussed earlier that dhaincha accumulated maximum green biomasses which were incorporated into the soil. Increased age of green manures helps in accumulation of higher biomass which might be the reason for increase in organic carbon content due to incorporation of aged green manures. These results are in complete agreement with the findings of Singh and Brar (1985), Yan and Li (1985), Shashidhar (1986) and Datt and Bharadwaj (1995).

Table.1 $\mathrm{pH}$, Organic carbon content at 30 DAS of maize and after harvest of maize and Bulk Density of soil after harvest of maize as influenced by in-situ incorporation of green manures and age of their incorporation

\begin{tabular}{|c|c|c|c|c|c|}
\hline \multirow[t]{2}{*}{ Treatments } & \multicolumn{2}{|c|}{ pH } & \multicolumn{2}{|c|}{$\begin{array}{c}\text { Organic carbon } \\
(\%)\end{array}$} & \multirow{2}{*}{$\begin{array}{l}\text { Bulk density } \\
\left(\mathrm{g} \mathrm{cm}^{-3}\right) \\
\text { At Harvest }\end{array}$} \\
\hline & $\begin{array}{c}\text { 30 } \\
\text { DAS }\end{array}$ & $\begin{array}{c}\text { At } \\
\text { Harvest }\end{array}$ & 30 DAS & $\begin{array}{c}\text { At } \\
\text { Harvest }\end{array}$ & \\
\hline \multicolumn{6}{|l|}{ Green Manures } \\
\hline Dhaincha & 7.73 & 7.80 & 0.73 & 0.51 & 1.19 \\
\hline Sunnhemp & 7.79 & 7.82 & 0.71 & 0.49 & 1.20 \\
\hline Pillipesara & 7.90 & 7.89 & 0.64 & 0.44 & 1.26 \\
\hline $\mathrm{S} \mathrm{Em} \pm$ & 0.08 & 0.09 & 0.01 & 0.01 & 0.02 \\
\hline C D $(\bar{P}=0.05)$ & NS & NS & 0.03 & 0.03 & NS \\
\hline \multicolumn{6}{|c|}{ Age of GM incorporation } \\
\hline 60 DAS & 7.73 & 7.82 & 0.75 & 0.54 & 1.16 \\
\hline 45 DAS & 7.82 & 7.84 & 0.68 & 0.46 & 1.23 \\
\hline 30 DAS & 7.87 & 7.89 & 0.65 & 0.43 & 1.26 \\
\hline $\mathrm{S} \mathbf{E m} \pm$ & 0.08 & 0.09 & 0.01 & 0.01 & 0.02 \\
\hline $\mathrm{C} \mathrm{D}(\overline{\mathbf{P}}=0.05)$ & NS & NS & 0.03 & 0.03 & NS \\
\hline Control & 8.00 & 8.00 & 0.40 & 0.40 & 1.28 \\
\hline Control Vs treated & 7.84 & 7.81 & 0.69 & 0.48 & 1.22 \\
\hline S Em \pm & 0.15 & 0.16 & 0.02 & 0.03 & 0.03 \\
\hline C D $(P=0.05)$ & NS & NS & 0.05 & 0.05 & NS \\
\hline \multicolumn{6}{|l|}{ Interaction ( $\mathbf{G} \times \mathbf{A})$} \\
\hline $\mathrm{S} \mathrm{Em} \pm$ & 0.14 & 0.15 & 0.02 & 0.02 & 0.03 \\
\hline $\mathrm{C} D(\overline{\mathbf{P}}=0.05)$ & NS & NS & NS & NS & NS \\
\hline $\mathrm{CV}(\%)$ & 2.2 & 2.4 & 3.8 & 6.3 & 8.4 \\
\hline
\end{tabular}


Table.2 Return per Rupee invested as influenced by in-situ incorporation of green manures and age of their incorporation

\begin{tabular}{|l|c|c|c|c|}
\hline & \multicolumn{4}{|c|}{ Age of Green Manure Incorporation } \\
\hline Green Manures & 60 DAS & 45 DAS & 30 DAS & MEAN \\
\hline Dhaincha & 2.86 & 4.01 & 3.05 & 3.31 \\
\hline Sunnhemp & 2.83 & 3.09 & 2.98 & 2.97 \\
\hline Pillipesara & 2.08 & 2.34 & 2.19 & 2.20 \\
\hline MEAN & 2.59 & 3.15 & 2.74 & \\
\hline
\end{tabular}

Table.3 Economics of different green manures incorporation and their ages of Incorporation of maize crop

\begin{tabular}{|l|l|c|c|c|c|c|}
\hline Treatments & $\begin{array}{c}\text { Gross } \\
\text { returns } \\
\text { from } \\
\text { grain (Rs) }\end{array}$ & $\begin{array}{c}\text { Gross } \\
\text { returns } \\
\text { from } \\
\text { stover } \\
\text { (Rs) }\end{array}$ & $\begin{array}{c}\text { Total gross } \\
\text { returns } \\
\text { (Rs) }\end{array}$ & $\begin{array}{c}\text { Total cost } \\
\text { of } \\
\text { cultivation } \\
\text { (Rs) }\end{array}$ & $\begin{array}{c}\text { Net } \\
\text { returns } \\
\text { (Rs) }\end{array}$ & $\begin{array}{c}\text { Rupee } \\
\text { per } \\
\text { rupee } \\
\text { invested } \\
\text { (Rs) }\end{array}$ \\
\hline $\mathbf{G}_{\mathbf{1}} \mathbf{A}_{\mathbf{1}}$ & 97426 & 1878 & 99304 & 39402 & 59902 & 1.52 \\
\hline $\mathbf{G}_{\mathbf{1}} \mathbf{A}_{\mathbf{2}}$ & 90365 & 1809 & 92174 & 35462 & 56712 & 1.60 \\
\hline $\mathbf{G}_{\mathbf{1}} \mathbf{A}_{\mathbf{3}}$ & 81299 & 1704 & 83003 & 34862 & 48141 & 1.38 \\
\hline $\mathbf{G}_{\mathbf{2}} \mathbf{A}_{\mathbf{1}}$ & 97032 & 1871 & 98902 & 39402 & 59500 & 1.51 \\
\hline $\mathbf{G}_{\mathbf{2}} \mathbf{A}_{\mathbf{2}}$ & 83983 & 1739 & 85722 & 35462 & 50260 & 1.42 \\
\hline $\mathbf{G}_{\mathbf{2}} \mathbf{A}_{\mathbf{3}}$ & 80835 & 1677 & 82512 & 34862 & 47650 & 1.37 \\
\hline $\mathbf{G}_{\mathbf{3}} \mathbf{A}_{\mathbf{1}}$ & 88887 & 1760 & 90647 & 39402 & 51245 & 1.30 \\
\hline $\mathbf{G}_{\mathbf{3}} \mathbf{A}_{\mathbf{2}}$ & 78719 & 1639 & 80357 & 35462 & 44895 & 1.27 \\
\hline $\mathbf{G}_{\mathbf{3}} \mathbf{A}_{\mathbf{3}}$ & 75849 & 1592 & 77442 & 34862 & 42580 & 1.22 \\
\hline $\mathbf{C o n t r o l}$ & 69133 & 1496 & 70629 & 30147 & 40482 & 1.34 \\
\hline
\end{tabular}

$\mathbf{G}_{\mathbf{1}}=$ Dhaincha; $\mathbf{G}_{\mathbf{2}}=$ Sunnhemp; $\mathbf{G}_{\mathbf{3}}=$ Pillipesara

$\mathbf{A}_{\mathbf{1}}=60$ days; $\mathbf{A}_{\mathbf{2}}=45$ days; $\mathbf{A}_{\mathbf{3}}=30$ days

Input cost: Land preparation: Rs 2625; Maize seed cost: Rs. 210/kg

Green manure seed cost: Dhaincha: Rs 50/kg; Sunnhemp: Rs 50/kg; Pillipesara: Rs 60/kg

Fertilizers cost: Urea: Rs.5.62/ kg; SSP: Rs 7.8/ kg; MOP: Rs 17.64/ kg

Chemicals cost: Chlorpyriphos: Rs. 260/ L; Dichlorvos: Rs. 480/ L; Carbofuran: Rs. 60/ kg Thidicarb: Rs. 2400/ kg; Spraying cost: Rs 300/ ha

Output cost: Rs. $12 / \mathrm{kg}$ (Maize grain cost); Rs $2 / 10 \mathrm{~kg}$ (stover cost)

Data pertaining to the $\mathrm{pH}$ of the soil $30 \mathrm{DAS}$ maize crop and at harvest reveals that $\mathrm{pH}$ of the soil did not vary significantly either due to incorporation of different green manures and age of incorporation of green manures or their interaction.

From the data it can be inferred that there was decrease in bulk density of soil after harvest of maize crop but decrease was nonsignificant either due to incorporation of different green manures or its age of incorporation.

A galaxy of workers has reported a decrease in bulk density due to incorporation of green manures such Ogbonna and Mabbayad (1983), Datt and Bhardawaj (1995), 
Sangakkara et al., (2008) and Sharma et al., (2010) but the later scientist reported a nonsignificant decrease in bulk density.

The gross returns, net returns was highest (Rs 99304.35, Rs 59902.35) where dhaincha was incorporated at 60 days followed by sunnhemp (Rs 98902.42, Rs 59500.42) incorporated at 60 days and dhaincha (Rs 92173.91, Rs 56711.91) incorporated at 45 days. The lowest net returns (Rs 40481.99) were obtained from control. However, the return per rupee investment (1.34) obtained from control plot was higher than pillipesara incorporated plot irrespective of their ages of incorporation. The highest return per rupee invested (1.59) was obtained where dhaincha was incorporated at 45 days.

Return per rupee invested on green manure is presented in the which indicates that among different green manures tested, return per rupee investment was maximum from dhaincha (Rs 3.31) followed by sunnhemp (Rs 2.97) and pillipesara (Rs 2.20). Due to age of incorporation, maximum return per rupee invested was with 45 days (Rs 3.15) age of incorporation of green manure followed by 30 days (Rs 2.74) and 60 days (Rs 2.59) age of incorporation of green manures. Among all the treatments tried, highest return per rupee investment was obtained where dhaincha was incorporated at 45 days (Rs 4.01) followed by sunnhemp incorporated at 45 days (Rs 3.09) and dhaincha incorporated at 30 days (Rs 3.05). Hiremath and Patel (1995) and Nooli (2001) also reported higher monetary advantages in terms of net returns and B: C ratio due to incorporation of green manures.

Returns per rupee investment was more with 30 days and 45 days aged green manure as less number of labour was required to grow the green manures. Since first sowing of green manure was done in the month of May, at that time, green manure required more number of frequent irrigations due to which cost of cultivation in growing green manure was high even though the yield obtained was higher when the green manure was incorporated at 60 days and in turn, the return obtained was less.

\section{References}

Bharadwaj, S. P., Prasad, S. N and Singh, G. 1981. Economizing nitrogen by green manures in rice-wheat rotation. Indian Journal of Agricultural Sciences. 51: 86-90.

Datt, N and Bharadwaj, K. K. R. 1995. Nitrogen contribution and soil improvement by legume green manuring in rice-wheat cropping on an acid clay loam soil. Journal of the Indian Society of Soil Science. 43: 603607.

Ghai, S. K., Rao, D. L. N and Batro, L. 1985. Comparative study of the potential of Sesbania for green manuring. Tropical Agriculture. 62: 52-56.

Hiremath, S. M and Patel, Z. G. 1995. Effect of winter season green manuring and nitrogen levels on rice yield and its economics under rice-rice cropping system. Karnataka Journal of Agricultural Sciences. 8: 330-335.

Nooli, S. S. 2001. Influence of in-situ green manuring of intercropped legumes on the performance of maize-safflower sequence cropping. M. Sc. (Agri.) thesis submitted for the University of Agricultural Sciences Dharwad.

Ogbonna, C. K. C and Mabbayad, B. B. 1983. Effect of the incorporation of 90- day old stylo as a green manure on the yield of corn (Zea mays L.) and on some soil properties. Philipp. Journal Crop Science. 8(3): 129-132.

Salam, M. A., Hamed, S. M. S., Shivaprasad, P., Tajuddin, E. and Thomas, Y., 1989, Performance of Sesbania rostrata in 
acid soils. International Rice Research Institute Newsletter, 14: 33-34.

Sangakkara, U. R., Weerasekera, D. N and Freyer, B. 2008. Green manuring for tropical organic cropping - A comparative analysis. $16^{\text {th }}$ IFOAM Organic World Congress, Modena, Italy. http://org/view/projects/conference.html Sharma, A. R., Ratan Singh, Dhyani, S. K and Dube, R. K. 2010. Effect of live mulching with annual legumes on performance of maize (Zea mays L.) and residual effect on following wheat (Triticum aestivum). Indian Journal of Agronomy. 55(3): 177-184.
Shashidhar, G. B. 1986. Legume effect on the succeeding crop in a sequential cropping system. M. Sc. (Agri.) Thesis University of Agricultural Sciences Bangalore.

Singh, B and Brar, S. P. 1985. Effect of organic manures and nitrogen on grain yield and soil properties in a maizewheat rotation. Journal of Research Punjab Agricultural University. 22: 243-252.

Yan, X. C and Li, D. M. 1985. Effect of planting green manure legumes on purple dry land soil. Journal of Soil Science. 16: 112-115.

\section{How to cite this article:}

Ghous Ali, Ch. Pulla Rao, A.S. Rao and Ashoka Rani, Y. 2018. Effect of in-situ Incorporation Green Manures on Soil Organic Carbon, pH, Bulk Density and Economics Involved in Its Incorporation. Int.J.Curr.Microbiol.App.Sci. 7(09): 62-67.

doi: https://doi.org/10.20546/ijcmas.2018.709.008 